\title{
Maize nitrogen recovery and dry matter production as affected by application of solid cattle manure subjected to various storage conditions
}

\author{
G.M . Shah ${ }^{1,2 *}$, G.A. Shah, ${ }^{1,3}$, J.C.J . Groot ${ }^{1}$, M.A.S. Raza ${ }^{4}$, N . Shahid, ${ }^{2}$ and E.A . Lantinga ${ }^{1}$ \\ ${ }^{1}$ Farming Systems Ecology Group, Wageningen University, the Netherlands. ${ }^{2}$ Department of Environmental \\ Sciences, COMSATS Institute of Information Technology, Vehari, Pakistan. ${ }^{3}$ Department of Agronomy, PMAS \\ Arid Agriculture University, Rawalpindi, Pakistan. ${ }^{4}$ Department of Agronomy, Islamia University of Bahawalpur, \\ Pakistan.*Corresponding author: gmshah1985@yahoo.com
}

\begin{abstract}
This study aimed to quantify the effects of contrasting composted methods of solid cattle manure (SCM) on dry matter (DM) yield and crop apparent $\mathrm{N}$ recovery (ANR) following manure application to maize land. Fresh SCM was stored as stockpiled, roofed, covered and composted heaps. After storage, the manures were incorporated in a sandy soil, and maize ANR both as a proportion of field applied $N\left(\mathrm{ANR}_{\mathrm{F}}\right)$ and collected $\mathrm{N}$ from the barn $\left(\mathrm{ANR}_{\mathrm{B}}\right)$, and $\mathrm{DM}$ yield was established at three successive growth stages: end of juvenile phase, start of grain filling, and physiological maturity.

During the storage period, on average $6 \%$ of the initial $\mathrm{N}_{\text {total }}$ was lost from covered, whereas this fraction was 12,21 and 33\% from roofed, stockpiled, and composted heaps, respectively. DM yield of maize increased with the application of all the manure types as compared to the unfertilized control, at the end of Juvenile (2.2 vs. 3.1-3.4 $\mathrm{Mg} \mathrm{ha}^{-1}$ ), grain filling (11.2 vs. 13.6-16.4 $\mathrm{Mg} \mathrm{ha}^{-1}$ ) and physiological maturity stages (13.9 vs. 15.3-15.9 $\left.\mathrm{Mg} \mathrm{ha}^{-1}\right)$. At a given growth stage, the greatest value was obtained from covered than roofed, stockpiled and composted manures. Maize ANR $_{\mathrm{F}}$ was the highest at start of grain filling $(20,29,31$, and $39 \%$ of the applied $\mathrm{N}$ for composted, stockpiled, roofed and covered treatments, respectively) but lower values were obtained at physiological maturity (12-21\%). The respective values in case of maize $\mathrm{ANR}_{\mathrm{B}}$ were 13, 23, 27 and $37 \%$ of total $\mathrm{N}$ taken from barn at the start of grain filling while it was also lower (8-20\%) at physiological maturity. It is concluded that storage of SCM under an impermeable plastic cover reduce $\mathrm{N}$ losses, increased DM yield and ANR thereby improves on-farm $\mathrm{N}$ cycling as compared to traditional stockpiling or composting.
\end{abstract}

Keywords: Solid cattle manure, storage conditions, organic farming, maize, $\mathrm{N}$ fertilizer value, nitrogen cycling 


\section{Introduction}

Solid cattle manure provides a valuable source of nitrogen $(\mathrm{N})$ for plant nutrition, but may cause agroenvironmental problems if its utilization is inefficient due to poor management (Schröder 2005; Scotti et al. 2015; Shah et al. 2016). After excretion in barns, solid cattle manure is either directly applied to the field or stockpiled and/or composted in the open air for a certain period of time prior to field application. When uncovered, the stored manure is subjected to ambient environmental conditions (i.e. rainfall, temperature, wind, and radiation), which influence gaseous emissions and leaching of $\mathrm{N}$ from the heaps (Kirchmann 1985; Pardo et al. 2015). These losses may not only contribute to environmental pollution but also reduce the $\mathrm{N}$ fertiliser value of the manure. Turning of the manure heap during composting exposes the inner fresh material to microbial colonisation which increases the manure decomposition rate and hence the temperature inside the heap. Additionally, the inner voids of the heap are exposed to the air, which will boost gaseous emissions (Amon et al. 2001; Parkinson et al. 2004; Sagoo et al. 2007; Hassouna et al. 2008). Some farmers stockpile solid cattle manure in a roofed building with the aim to protect it against precipitation and therefore to reduce especially leaching losses (Mosquera et al. 2006), however, this is not a common practice. All these storage methods result in substantial loss of $\mathrm{N}$ up to about $50 \%$ of the initial $\mathrm{N}$ content from the heaps (Shah et al. 2012b). Attempts have been and are being made to reduce the solid cattle manure storage $\mathrm{N}$ losses. These include compaction and/or covering of manure heaps, use of chemical as well as biochemical additives, and application of additional straw (Sommer and Møller 2000; Chadwick 2005; Yamulki 2006; Ndegwa et al. 2008; Shah et al. 2013; Pardo et al. 2015). However, all these storage conditions not only affect the level of $\mathrm{N}$ losses but also determine the characteristics of the end product, which can be decisive for subsequent $\mathrm{N}$ release for crop uptake after manure application (Kirchmann 1985; Shah et al. 2012b; Rashid et al. 2013). Covered storage creates anaerobic conditions which transforms high molecular weight compounds (e.g. plant fibre, microbial and metabolic proteins) into easily degradable and low molecular weight compounds such as fatty

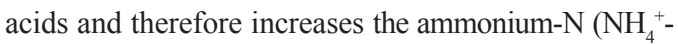
N) content of manure (Kirchmann and Witter 1989). The organic matter decomposed under this method comprises mainly of cellulose, hemicellulose and soluble compounds. Under aerobic conditions, a large part of the manure $\mathrm{NH}_{4}^{+}-\mathrm{N}$ can be lost via $\mathrm{NH}_{3}$ volatilisation or transformed into organic N. In addition, humified organic material of high stability with a low $\mathrm{C} / \mathrm{N}$ ratio is produced (Kirchmann 1985). Consequently, microbial decomposition and $\mathrm{N}$ release from these stored manures might affect their $\mathrm{N}$ fertilizer value. Thus, we believe that it is indispensable to take also into account the downstream impacts of the storage methods i.e. on crop yield and $\mathrm{N}$ recovery after land application in order to improve on-farm $\mathrm{N}$ cycling within the livestockmanure-soil-crop continuum.

After soil application, part of the inorganic $\mathrm{N}$ is immobilized by microbes, fixed by clay and/or adsorbed on negatively charged surfaces. This immobilized and retained $\mathrm{N}$ as well as the organic $\mathrm{N}$ fraction of applied manure has to be first mineralized or desorbed before it is available for plant uptake. All these $\mathrm{N}$ transformations are rather complex and controlled by manure type, their characteristics, and storage conditions (Kirchmann 1985; Thomsen and Olesen 2001; Shah et al. 2012a, b; Shah et al. 2016). It has shown in earlier studies that relatively greater amount of $\mathrm{N}$ can end up in plants from covered/anaerobically-stored as compared to the composted/aerobically-stored manures 
(Kirchmann 1985; Thomsen 2001, Thomsen and Olesen 2000; Takahashi et al. 2004; Shah et al. 2012a, 2016). Of these studies evaluating DM yield and $\mathrm{N}$ recovery from stored manures, mostly focused on sheep manure (Thomsen 2001; Thomsen and Olesen 2000), poultry manure (Takahashi et al. 2004) and cattle manure on grasslands (Shah et al. 2012a), whereas only a little is known when stored cattle manures are applied to arable land (Shah et al. 2016). Due to lack of this information the farmers mix their animal manures in the soil just before sowing and use abundant chemical fertilizer to ensure maximum production. This over fertilization not only increases the cost of production but also contribute to the environmental pollution. Thus both from economic and environmental point of view, it is a crucial to estimate crop DM yield and $\mathrm{N}$ recovery from stored cattle manures during a growing season in order to optimize the doze of $\mathrm{N}$ fertilizer for sustainable crop production.

The objectives of this study were therefore to quantify the effects of contrasting storage methods of solid cattle manure on DM yield and apparent $\mathrm{N}$ recovery from both field applied $\mathrm{N}\left(\mathrm{ANR}_{\mathrm{F}}\right)$ and $\mathrm{N}$ collected from the barn $\left(\mathrm{ANR}_{\mathrm{B}}\right)$, after application to maize land.

\section{Materials and Methods}

\subsection{Description of the experimental site}

The study was carried out at the Organic Experimental and Training Farm Droevendaal, located $1 \mathrm{~km}$ north of the city of Wageningen, the Netherlands (latitude $55^{\circ} 99^{\prime} \mathrm{N}$ and longitude $5^{\circ} 66^{\prime} \mathrm{E}$ ). The climate is temperate maritime with average summer and winter temperatures of about $19{ }^{\circ} \mathrm{C}$ and $2{ }^{\circ} \mathrm{C}$, respectively. The mean annual rainfall is $765 \mathrm{~mm}$ with a relatively high inter-annual variability. Experimental field on the farm was not cultivated over the last 3 years and was covered with ryegrass. The soil (pH 5.23, C/N 18) was sandy
( $80 \%$ particles 50 to $2,000 \mu \mathrm{m}$ and $4 \%$ particles $<2$ $\mu \mathrm{m})$ and contained $1.1 \mathrm{~g} / \mathrm{kg} \mathrm{N}, 3.5 \%$ organic matter $80 \mathrm{mg} / \mathrm{kg} \mathrm{K}$, and $4.7 \mathrm{mg} / \mathrm{kg} \mathrm{P}$.

\subsection{Manure storage treatments and total nitrogen losses}

Fresh solid cattle manure (SCM) was collected from a naturally ventilated sloping-floor barn with young beef cattle, where chopped cereal straw were used as bedding material at a daily rate of $5 \mathrm{~kg}$ per livestock unit ( $1 \mathrm{LU}=500 \mathrm{~kg}$ of live body mass). Immediately thereafter, portions of $10 \mathrm{Mg}$ of SCM were put on a clean concrete floor outdoors to make conical heaps with a height of about $1.5 \mathrm{~m}$ and a base diameter of about $5 \mathrm{~m}$. There were four SCM storage methods: (i) stockpiled heap in the open air, (ii) roofed heap: stockpiled heap under a plastic roof, (iii) covered heap: stockpiled heap covered with an impermeable plastic sheet, and (iv) composted heap with monthly turnings. All the treatments were arranged in a randomized complete block design with three replicates. The manure heaps were build-up in bunkers bounded by one course of concrete blocks around three sides (approximately $0.5 \mathrm{~m}$ high) and a ridge of sand forming the fourth side (30 $\mathrm{cm}$ high). For each of the covered heaps, an impermeable plastic sheet $(0.15 \mathrm{~mm}$ thick polyethylene film) was lined at its bottom and at the top. The edges of the plastic sheet were covered with sand-filled plastic sacks in order to block the inflow of air into the heap. For each roofed heap, an artificial roof was built by installing a thick impermeable plastic sheet $(0.15 \mathrm{~mm}$ thick polyethylene film) on four curved iron posts each with a height of $4 \mathrm{~m}$ in the middle. The manure was stored at composting facility of Wageningen University, the Netherlands for 160 days starting from the $1^{\text {st }}$ week of December 2009 until the $2^{\text {nd }}$ week of May 2010. At the end of the experiment, each heap was weighed to estimate the amount of remaining SCM in each treatment. 
Both at the start and end of the storage period, three manure composite samples (ca. $2 \mathrm{~kg}$ fresh wt.) were collected from each heap. Each composite sample consisted of 20-30 sub-samples taken by hand from different locations of a heap. The samples were stored at $-18{ }^{\circ} \mathrm{C}$ until analysis in order to prevent $\mathrm{N}$ transformations. Before analysis, the samples were thawed at room temperature $\left(20^{\circ} \mathrm{C}\right)$ and soon afterwards ( $\sim 20$ minutes) chopped with a cutting machine in order to cut straw particles into small pieces $(\leq 2$ $\mathrm{cm})$. From this material, representative sub-samples of about $100 \mathrm{~g}$ were analysed for total $\mathrm{N}, \mathrm{NH}_{4}{ }^{+} \mathrm{N}$, nitrate- $\mathrm{N}\left(\mathrm{NO}_{3}^{-}-\mathrm{N}\right), \mathrm{pH}, \mathrm{DM}$ and raw ash (Table 1). Total $\mathrm{N}$ was measured after Kjeldahl digestion $\left(\mathrm{MAF}_{\mathrm{F}}\right.$
1986). Contents of $\mathrm{NH}_{4}^{+}-\mathrm{N}$ and $\mathrm{NO}_{3}^{-}-\mathrm{N}$ were measured in a $1: 10$ manure $/ 0.01 \mathrm{M} \mathrm{CaCl}_{2}$ extract by means of segmented-flow analysis (Houba et al. 1989). The $\mathrm{pH}$ was measured in the same extract using a $\mathrm{pH}$ meter (inoLab pH meter level 1, WTW GmbH \& Co. KG, Germany). DM was determined after drying the samples at $105{ }^{\circ} \mathrm{C}$ for 24 hours (Anonymous 1998). Subsequently, raw ash content was determined gravimetrically through ignition of the dried samples at $525^{\circ} \mathrm{C}$ for 6 hours (Anonymous 1998) with organic matter (OM) being equal to the ignition losses. Total $\mathrm{C}$ was assumed to be $50 \%$ of the OM (Pettygrove et al. 2009). Total $\mathrm{N}$ losses from each heap during the storage period was determined by the mass balance method.

Table 1. Chemical composition of solid cattle manure (means and standard errors; $n=3$ ) at the start of their application to maize land.

\begin{tabular}{|c|c|c|c|c|c|c|c|c|c|}
\hline \multirow[t]{2}{*}{ Treatments } & \multirow{2}{*}{$\begin{array}{l}\text { DM } \\
(\%)\end{array}$} & $\mathrm{C}_{\text {total }}$ & $\mathrm{N}_{\text {total }}$ & \multirow[t]{2}{*}{$\mathrm{N}_{\min .}$} & \multirow{2}{*}{$\begin{array}{c}\mathrm{N}_{\min .} / \mathrm{N}_{\text {total }} \\
\text { (\%) }\end{array}$} & \multirow{2}{*}{$\begin{array}{l}\mathrm{C} / \mathrm{N} \\
\text { ratio }\end{array}$} & $\mathrm{P}_{2} \mathrm{O}_{5}$ & $\mathrm{~K}_{2} \mathrm{O}$ & \multirow{2}{*}{$\begin{array}{c}\mathrm{pH}- \\
\mathrm{CaCl}_{2} \text { \$ }\end{array}$} \\
\hline & & \multicolumn{2}{|c|}{$\left(\mathrm{g} \mathrm{kg}^{-1} \mathrm{DM}\right)$} & & & & \multicolumn{2}{|c|}{$\left(\mathrm{g} \mathrm{kg}^{-1} \mathrm{DM}\right)$} & \\
\hline Fresh manure & $21.7 \pm 0.5$ & $357 \pm 2.2$ & $29.7 \pm 0.7$ & $3.7 \pm 0.4$ & 12 & $12.0 \pm 0.3$ & $14.1 \pm 0.9$ & $42.4 \pm 1.8$ & 8.0 \\
\hline Roofed manure & $21.1 \pm 0.0$ & $338 \pm 4.8$ & $29.7 \pm 0.4$ & $4.2 \pm 0.5$ & 14 & $11.4 \pm 0.0$ & $15.1 \pm 0.8$ & $45.9 \pm 2.1$ & 8.1 \\
\hline Stockpiled manure & $21.2 \pm 0.3$ & $339 \pm 2.4$ & $27.3 \pm 1.1$ & $2.9 \pm 0.2$ & 10 & $12.4 \pm 0.4$ & $12.2 \pm 0.9$ & $36.8 \pm 1.5$ & 8.1 \\
\hline Composted manure & $22.2 \pm 0.3$ & $339 \pm 3.9$ & $27.2 \pm 1.4$ & $2.2 \pm 0.2$ & 9 & $12.5 \pm 0.6$ & $19.0 \pm 0.5$ & $53.6 \pm 1.1$ & 8.3 \\
\hline Covered manure & $20.5 \pm 0.2$ & $340 \pm 3.3$ & $30.4 \pm 0.4$ & $5.1 \pm 0.3$ & 17 & $11.2 \pm 0.2$ & $18.5 \pm 1.0$ & $51.7 \pm 2.0$ & 7.8 \\
\hline
\end{tabular}

$\$$ Standard errors $<0.1$

\subsection{Maize DM yield and $N$ recovery}

After the storage phase, all the stored manures together with fresh manure taken directly from the barn (total $\mathrm{N} 29.7 \mathrm{~g} \mathrm{~kg}^{-1} \mathrm{DM}$, mineral $\mathrm{N} 3.7 \mathrm{~g} \mathrm{~kg}^{-1} \mathrm{DM}$ and $\mathrm{C} / \mathrm{N}$ ratio 12) were incorporated (on May 11, 2010) in the top $10 \mathrm{~cm}$ of an arable field of the farm at an application rate of $170 \mathrm{~kg} \mathrm{~N} \mathrm{a}^{-1}$. Treatments comprised: (i) control (unfertilised), (ii) fresh manure, (iii) stockpiled manure, (iv) roofed manure, (v) covered manure, and (vi) composted manure. All the treatments were arranged in a randomised complete block design with four replicates. The plot size was $15 \mathrm{~m} \times 4.5 \mathrm{~m}$. One week after manure incorporation (on May 19, 2010), maize seeds (cultivar: Lapriora) were sown at $6 \mathrm{~cm}$ depth and a density of 11 plants $\mathrm{m}^{-2}$. In each plot, there were 6 rows of maize plants with a row spacing of $75 \mathrm{~cm}$. The experimental area was weeded manually during vegetative growth period of maize.

In order to study the dynamics of $\mathrm{N}$ uptake and apparent $\mathrm{N}$ recovery (ANR) in time, maize crop samples were taken at three successive growth stages: 55 days after sowing (DAS), i.e. at the end of juvenile stage, 
98 DAS (start of grain filling) and 131 DAS (physiological maturity). These growth stages were based on Gungula et al. (2003). During the first two harvests, 10 plants were selected randomly from the two inner rows (rows 2 and 5) of each plot, and were manually cut at ground level using a sharp knife. At final harvest, all the plants in the remaining two middle rows (rows 3 and 4) were cut mechanically at $10 \mathrm{~cm}$ height by a mechanical maize harvester and the actual number of harvested plants per plot was counted. At this growth stage, stubble DM and $\mathrm{N}$ yields represent about $4 \%$ of their respective harvested yields above $10 \mathrm{~cm}$ (M. Ali, personal communication) which were added to the obtained DM and $\mathrm{N}$ yields in order to enable a fair comparison with the first two growth stages. The outer two rows (rows 1 and 6) were not used for the experiment in order to exclude border effects. At each harvest, fresh maize biomass was measured in the field and subsequently chopped with a cutting machine in order to take representative fresh samples of about $500 \mathrm{~g}$. Subsequently, the samples were ovendried at $70{ }^{\circ} \mathrm{C}$ for 48 hours, ground to pass $1 \mathrm{~mm}$ sieve and analysed for total $\mathrm{N}$ content through Kjeldahl digestion $\left(\mathrm{MAF}_{\mathrm{F}} 1986\right)$. Maize apparent $\mathrm{N}$ recovery in the field $\left(\mathrm{ANR}_{\mathrm{F}}\right)$ was calculated as:

$$
\operatorname{ANR}_{\mathrm{F}}(\%)=\frac{\left(\mathrm{N}_{\mathrm{m}} \times \mathrm{DM}_{\mathrm{m}}\right)-\left(\mathrm{N}_{0} \times \mathrm{DM}_{0}\right)}{\mathrm{TN}_{\mathrm{a}}} \times 100
$$

Where $\mathrm{N}_{\mathrm{m}}$ is maize $\mathrm{N}$ content $\left(\mathrm{mg} \mathrm{N}(\mathrm{kg} \mathrm{DM})^{-1}\right)$ in the manured plots, $\mathrm{DM}_{\mathrm{m}}$ is maize DM yield $\left(\mathrm{kg} \mathrm{ha}^{-1}\right)$ in the manured plots, $\mathrm{N}_{0}$ is maize $\mathrm{N}$ content $(\mathrm{mg} \mathrm{N}$ $\left.(\mathrm{kg} \mathrm{DM})^{-1}\right)$ in the unfertilised plots, $\mathrm{DM}_{0}$ is maize DM yield $\left(\mathrm{kg} \mathrm{ha}^{-1}\right)$ in the unfertilised plots and $\mathrm{TN}_{\mathrm{a}}$ is total amount of $\mathrm{N}$ applied with manure $\left(\mathrm{kg} \mathrm{ha}^{-1}\right)$

Thereafter, maize apparent $\mathrm{N}$ recovery of the $\mathrm{N}$ collected from the barn $\left(\mathrm{ANR}_{\mathrm{B}}\right)$ was calculated as:

$$
\operatorname{ANR}_{\mathrm{B}}(\%)=\frac{\left(\mathrm{TN}_{\text {barn }}-\mathrm{TNloss}_{\text {storage }}\right) \times \mathrm{ANR}_{\mathrm{F}}}{\mathrm{TN}_{\text {barn }}} \times 100
$$

Where $\mathrm{TN}_{\text {barn }}$ is total amount of manure $\mathrm{N}$ taken from the barn (kg), TNloss $s_{\text {storage }}$ is total $\mathrm{N}$ lost during storage $(\mathrm{kg})$ and $\mathrm{ANR}_{\mathrm{F}}$ is maize apparent $\mathrm{N}$ recovery in the field (\%).

\subsection{Maize composition}

The dried maize samples were ground with a ball-mill (Retsch, Germany) and subsequently extracted in $5 \mathrm{ml}$ of $80 \%$ ethanol for 20 minutes at $80{ }^{\circ} \mathrm{C}$. The supernatant was discharged, the residues were centrifuged and the obtained pellets were washed three times with $80 \%$ ethanol before vacuum drying in order to remove already existing soluble sugars and to accurately analyse starch (converted to glucose) in the samples. Starch was enzymatically converted to glucose with thermostable $\alpha$-amylase (Serva 13452) in water at $90{ }^{\circ} \mathrm{C}$, and subsequently at $60{ }^{\circ} \mathrm{C}$ with amyloglucosidase (Fluka 10115) in $50 \mathrm{mM}$ citrate buffer with $\mathrm{pH}=4.6$. The obtained starch extracts were analysed on a Dionex ICS5000 HPLC equipped with a CarboPac1 $(250 \times 2 \mathrm{~mm})$ column eluted with $100 \mathrm{mM}$ $\mathrm{NaOH}$ and $12.5 \mathrm{mM}$ sodium acetate.

Cell wall contents, i.e. cellulose, hemicellulose and lignin, in the maize plant samples were determined gravimetrically after extracting the dried samples with $\mathrm{H}_{2} \mathrm{SO}_{4}$ as outlined in Dence (1992) (the NDF/ ADF method).

\subsection{Statistical analysis}

Total $\mathrm{N}$ losses from the heaps during storage, and maize DM yield, $\mathrm{N}$ uptake and ANR data after manure application in the arable field were statistically 
If the overall main effects were significant, differences among the treatments were further compared using Fisher's protected least significant difference (LSD) test at $5 \%$ probability level. The differences in starch, cellulose, hemicellulose and lignin yields at various maturity stages of maize were also statistically tested as described above.

\section{Results and Discussion}

\section{1. $N$ losses during storage of SCM}

Mass balances during the manure storage phase revealed that highest total $\mathrm{N}$ losses occurred in the composted heaps and lowest in the covered heaps (Figure $1, \mathrm{P}<0.05)$. On average, about $6 \%$ of the initial $\mathrm{N}$ total was lost from the covered heaps whereas this fraction was $12 \%$ from the roofed, $21 \%$ from the stockpiled, and 33\% from the composted heaps (Figure 1). These higher $\mathrm{N}$ losses from the stockpiled and composted heaps as compared to the others can be associated with a higher degree of aerobic decomposition stimulated by diffusion of air into these heaps due to (1) the presence of straw in both heaps and (2) regular turning of the composted heap (Parkinson et al. 2004).

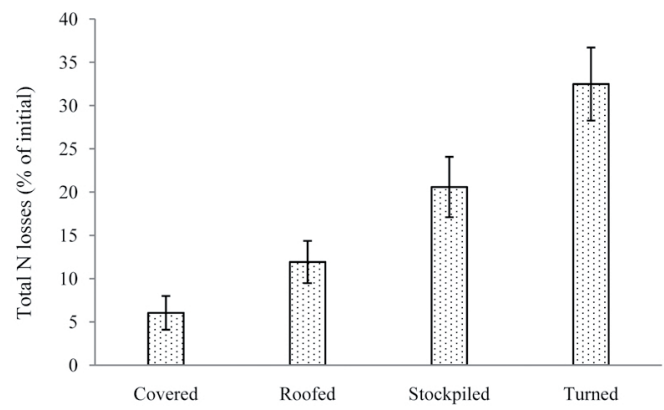

Figure 1. Total $\mathrm{N}$ losses from solid cattle manure when subjected to various storage conditions. Error bars represent the standard error of the means $( \pm)$.
In case of the composted heaps, turning increased air exchange through the materials and stimulated aerobic decomposition processes which will stimulate the process of $\mathrm{NH}_{3}$ emission (Amon et al. 2001; Parkinson et al. 2004). Covered storage reduced these $\mathrm{N}$ losses by about a factor five relative to composted heap. This could be ascribed to blockage of air circulation through the heaps which minimize aerial losses and creates near-anaerobic conditions (Kirchmann 1985; Hansen et al. 2006). Further, the formation of nitrate and nitrite is restricted under anaerobic conditions and thereby also the occurrence of denitrification losses (Kirchmann 1985). Consequently, mineral $\mathrm{N}$ content in covered manure was greatly increased at the end of the storage period (Table 1). This increase is important from an agronomical viewpoint especially in case of organic agricultural practices where the use of artificial fertiliser is prohibited. However, due to increased mineral $\mathrm{N}$ content along with a high $\mathrm{pH}$ of covered manure, compensatory losses may occur through increased $\mathrm{NH}_{3}$ emissions after its land application, when left untreated (e.g. Amon et al. 2001; De Vries et al. 2015). Benefits of manure covering can be maximised through soil incorporation (Webb et al. 2012), irrigation or using additives like lava meal which adsorb ammonium-N (Shah et al. 2012c). Visual observations during the experimental work revealed that the surface of the roofed heaps remained open and porous, especially during the first month of the storage, allowing $\mathrm{NH}_{3}$ to diffuse easily into the atmosphere. On the other hand, the stockpiled heaps in the open air were subjected to the exposure of weather (wetting and drying), which lead to the formation of a surface crust and thereby creating a physical barrier to gaseous $\mathrm{N}$ emissions. 


\subsection{Crop dry matter yield and $N$ recovery}

Maize DM yield, $\mathrm{ANR}_{\mathrm{F}}$ and $\mathrm{ANR}_{\mathrm{B}}$ are presented in Table 2. The DM yield increased $(\mathrm{P}<0.05)$ with the manure application as compared to the unfertilized control (Table 2). Among the manure types, it was the highest in case of covered and the lowest from composted manure, on all crop growth stages. Similarly, maize $\mathrm{ANR}_{\mathrm{F}}$ was lower from composted manure as compared to covered manure irrespective to the growth stage. The reasons for this appeared to be (i) the relatively greater loss of readily degradable $\mathrm{N}$ compounds already during composting resulting in lower mineral $\mathrm{N}$ contents (Table 1), and (ii) conversion of a part of the remaining $\mathrm{N}$ into chemical forms that are more stable than those originally present before composting (Kirchmann 1985; Kirchman and Witter 1989; Thomsen 2001). When losses during storage were included in the calculations to arrive at an apparent $\mathrm{N}$ recovery for the whole manure handling chain with the barn as starting point $\left(\mathrm{ANR}_{\mathrm{B}}\right)$, almost three times lower value was observed for com- posted than for covered manures $\left(\mathrm{ANR}_{\mathrm{B}}=13\right.$ vs. $37 \%$ at grain filling stage, respectively; Table 2). Interestingly, despite an observed $6 \%$ loss of the initial total $\mathrm{N}$ during the covered storage, $\mathrm{ANR}_{\mathrm{F}}$ from covered manure was higher than from fresh manure taken directly from the barn (i.e. $\mathrm{ANR}_{\mathrm{B}}=37$ vs. 27 at grain filling stage, respectively; Table 2). This clearly indicates that a significant fraction of the initial organic $\mathrm{N}$ of covered manure was mineralised during storage phase. Consequently, total mineral $\mathrm{N}$ increased by $41 \%$ after covered storage with respect to fresh manure and thereby increased the $\mathrm{N}$ fertiliser value of this currently underutilised manure storage practice. Interestingly, the apparent $\mathrm{N}$ ended up in above ground biomass varied among the maize growth stages as observed at each harvesting event (Table 2). Maize $\mathrm{ANR}_{\mathrm{F}}$ appeared to be highest at the start of grain filling $(20,29,31$, and $39 \%$ of the applied $\mathrm{N}$ for composted, stockpiled, roofed and covered treatments, respectively; Table 2), but lower values were obtained at physiological maturity stage (12-21\%).

Table 2. Mean dry matter (DM) yield, nitrogen $(\mathrm{N})$ uptake, and apparent $\mathrm{N}$ recovery expressed as fraction of total $\mathrm{N}$ applied to the field $\left(\mathrm{ANR}_{\mathrm{F}}\right)$ and as fraction of total $\mathrm{N}$ taken from the barn $\left(\mathrm{ANR}_{\mathrm{B}}\right)$ at various growth stages of maize.

\begin{tabular}{|c|c|c|c|c|c|c|c|c|c|c|c|c|}
\hline \multirow[t]{3}{*}{ Treatment } & \multicolumn{4}{|c|}{ End of the juvenile } & \multicolumn{4}{|c|}{ Start of the grain filling } & \multicolumn{4}{|c|}{ Physiological maturity } \\
\hline & DM yield & $\mathrm{N}$ uptake & $\mathrm{ANR}_{\mathrm{F}}$ & $\overline{\mathrm{ANR}_{\mathrm{B}}}$ & DM yield & $\mathrm{N}$ uptake & $\mathrm{ANR}_{\mathrm{F}}$ & $\overline{\mathrm{ANR}_{\mathrm{B}}}$ & DM yield & N uptake & $\mathrm{ANR}_{\mathrm{F}}$ & $\mathrm{ANR}_{\mathrm{B}}$ \\
\hline & $\left(\mathrm{Mg} \mathrm{ha}^{-1}\right)$ & $\left(\mathrm{kg} \mathrm{ha}^{-1}\right)$ & \multicolumn{2}{|c|}{$(\%)$} & $\left(\mathrm{Mg} \mathrm{ha}^{-1}\right)$ & $\left(\mathrm{kg} \mathrm{ha}^{-1}\right)$ & \multicolumn{2}{|c|}{$(\%)$} & $\left(\mathrm{Mg} \mathrm{ha}^{-1}\right)$ & $\left(\mathrm{kg} \mathrm{ha}^{-1}\right)$ & \multicolumn{2}{|c|}{$(\%)$} \\
\hline Zero & $2.2^{\mathrm{a} \dagger}$ & $68^{\mathrm{a}}$ & & & $11.2^{\mathrm{a}}$ & $155^{\mathrm{a}}$ & & & $13.9^{\mathrm{a}}$ & $166^{\mathrm{a}}$ & & \\
\hline Fresh & $3.1^{\mathrm{b}}$ & $100^{\mathrm{b}}$ & $19^{\mathrm{a}}$ & & $14.4^{\mathrm{bc}}$ & $204^{\mathrm{c}}$ & $28^{\mathrm{b}}$ & & $15.9^{\mathrm{b}}$ & $195^{\mathrm{bc}}$ & $17^{\mathrm{ab}}$ & \\
\hline Roofed & $3.2^{\mathrm{b}}$ & $102^{\mathrm{bc}}$ & $20^{\mathrm{ab}}$ & $18^{\mathrm{b}}$ & $14.7^{\mathrm{bc}}$ & $208^{\mathrm{c}}$ & $31^{\mathrm{b}}$ & $27^{\mathrm{b}}$ & $15.3^{\mathrm{b}}$ & $186^{\mathrm{b}}$ & $12^{\mathrm{a}}$ & $11^{\mathrm{a}}$ \\
\hline Stockpiled & $3.2^{\mathrm{b}}$ & $98^{\mathrm{b}}$ & $18^{\mathrm{a}}$ & $14^{\mathrm{ab}}$ & $15.5^{\mathrm{cd}}$ & $205^{\mathrm{c}}$ & $29^{\mathrm{b}}$ & $23^{\mathrm{b}}$ & $15.6^{\mathrm{b}}$ & $191^{\mathrm{bc}}$ & $15^{\mathrm{a}}$ & $12^{\mathrm{a}}$ \\
\hline Composted & $3.1^{\mathrm{b}}$ & $97^{\mathrm{b}}$ & $17^{\mathrm{a}}$ & $11^{\mathrm{a}}$ & $13.6^{\mathrm{b}}$ & $190^{\mathrm{b}}$ & $20^{\mathrm{a}}$ & $13^{\mathrm{a}}$ & $15.2^{\mathrm{b}}$ & $187^{\mathrm{b}}$ & $12^{\mathrm{a}}$ & $8^{\mathrm{a}}$ \\
\hline Covered & $3.4^{\mathrm{b}}$ & $107^{\mathrm{c}}$ & $23^{\mathrm{b}}$ & $26^{\mathrm{c}}$ & $16.4^{\mathrm{d}}$ & $222^{\mathrm{d}}$ & $39^{c}$ & $37^{\mathrm{c}}$ & $15.9^{\mathrm{b}}$ & $201^{\mathrm{c}}$ & $21^{\mathrm{b}}$ & $20^{\mathrm{b}}$ \\
\hline
\end{tabular}

$\uparrow$ Values in the same column with different letters as superscript differ significantly $(\mathrm{P}<0.05)$ 
The respective values in case of maize $\mathrm{ANR}_{\mathrm{B}}$ were $13,23,27$ and $37 \%$ of total $\mathrm{N}$ taken from the barn as established at the start of grain filling, while it was also lower (8-20\%) at physiological maturity (Table 2 ). During the 33 days of the grain filling stage, on average $1500 \mathrm{~kg} \mathrm{NDF} \mathrm{ha}^{-1}$ and $15 \mathrm{~kg} \mathrm{~N} \mathrm{ha}^{-1}$ was lost from the manure storage treatments (Figures 2ab; Table 3ab). Consequently, both maize $\mathrm{ANR}_{\mathrm{F}}$ and $\mathrm{ANR}_{\mathrm{B}}$ were decreased at physiological maturity with respect to the start of grain filling (Table 2). Moreover, only small differences were found in final starch yield between all manure treatments at physiological maturity (Figures 2bc, Table 3a). The aboveground DM mass increased during the period of grain filling stage in case of zero, fresh, roofed and composted treatments, but decreased in case of covered treatment and remained unchanged in the stockpiled treatment (Figure 2ad). This can be attributed to the higher availability and crop uptake of $\mathrm{N}$ in the covered treatment that had probably enhanced the leaf area of maize, which resulted in a higher DM yield as compared to the other manure storage treatments at the start of grain filling stage (Table 2). Nevertheless, this later has created shading of the bottom leaves in the canopy. Due to shading effects, faster senescence of the bottom leaves occurred. This has resulted in NDF and N losses during grain filling phase (Figure 2ab). Consequently, the calculated maize ANR at physiological maturity was lower than at the start of grain filling (Table 2).

During the grain filling phase, starch accumulation in the cob is mainly reliant on export of assimilates from the source leaves (Prioul and Schwebel-Dugué 1992). Since this process largely depends on the presence of sufficient photosynthetically active (green) leaves in the top of the canopy and the sink strength of the cob, the differences in $\mathrm{N}$ availability between the treatments had only marginal effects on final starch yield at physiological maturity (Figure 2bc).

Table 3a. Mean dry matter (DM), nitrogen $(\mathrm{N})$ and starch yields of silage maize at various growth stages.

\begin{tabular}{|c|c|c|c|c|c|c|c|c|c|c|c|c|c|c|c|c|c|c|}
\hline \multirow[t]{3}{*}{ Growth stage } & \multicolumn{3}{|c|}{ Zero } & \multicolumn{3}{|c|}{ Fresh } & \multicolumn{3}{|c|}{ Roofed } & \multicolumn{3}{|c|}{ Stockpiled } & \multicolumn{3}{|c|}{ Composted } & \multicolumn{3}{|c|}{ Covered } \\
\hline & DM & $\mathrm{N}$ & Starch & DM & $\mathrm{N}$ & Starch & DM & $\mathrm{N}$ & Starch & DM & $\mathrm{N}$ & Starch & DM & $\mathrm{N}$ & Starch & DM & $\mathrm{N}$ & Starch \\
\hline & $\left(\mathrm{Mg} \mathrm{ha}^{-1}\right)$ & \multicolumn{2}{|c|}{$\left(\mathrm{kg} \mathrm{ha}^{-1}\right)$} & $\left(\mathrm{Mg} \mathrm{ha}^{-1}\right)$ & \multicolumn{2}{|c|}{$\left(\mathrm{kg} \mathrm{ha}^{-1}\right)$} & $\left(\mathrm{Mg} \mathrm{ha}^{-1}\right)$ & \multicolumn{2}{|c|}{$\left(\mathrm{kg} \mathrm{ha}^{-1}\right)$} & $\left(\mathrm{Mg} \mathrm{ha}^{-1}\right)$ & \multicolumn{2}{|c|}{$\left(\mathrm{kg} \mathrm{ha}^{-1}\right)$} & $\left(\mathrm{Mg} \mathrm{ha}^{-1}\right)$ & \multicolumn{2}{|c|}{$\left(\mathrm{kg} \mathrm{ha}^{-1}\right)$} & $\left(\mathrm{Mg} \mathrm{ha}^{-1}\right)$ & \multicolumn{2}{|c|}{$\left(\mathrm{kg} \mathrm{ha}^{-1}\right)$} \\
\hline End of juvenile & $2.2^{a+\phi}$ & $68^{3}$ & $5^{\mathrm{a}}$ & $3.1^{a}$ & $100^{a}$ & $7 \mathrm{a}$ & $3.2^{\mathrm{a}}$ & $102^{a}$ & $8^{a}$ & $3.2^{\mathrm{a}}$ & $98^{a}$ & $7^{a}$ & $3.1^{\mathrm{a}}$ & $97^{a}$ & $7^{a}$ & $3.4^{\mathrm{a}}$ & $107^{a}$ & $7^{a}$ \\
\hline Start of grain filling & $11.2^{\mathrm{b}}$ & $155^{b}$ & $670^{b}$ & $14.4^{\mathrm{b}}$ & $204^{b}$ & $907^{\mathrm{b}}$ & $14.7^{\mathrm{b}}$ & $208^{c}$ & $1100^{b}$ & $15.5^{\mathrm{b}}$ & $205^{c}$ & $1457^{\mathrm{b}}$ & $13.6^{\mathrm{b}}$ & $190^{\mathrm{b}}$ & $1031^{\mathrm{b}}$ & $16.4^{\mathrm{b}}$ & $222^{\circ}$ & $1243^{\mathrm{b}}$ \\
\hline Physiological maturity & $13.9^{\circ}$ & $166^{\mathrm{b}}$ & $4753^{\circ}$ & $15.9^{\mathrm{c}}$ & $195^{\mathrm{b}}$ & $5535^{\mathrm{c}}$ & $15.3^{\mathrm{b}}$ & $186^{\mathrm{b}}$ & $5274^{c}$ & $15.6^{\mathrm{b}}$ & $191^{\mathrm{b}}$ & $5036^{\circ}$ & $15.2^{\mathrm{c}}$ & $187^{b}$ & $5039^{\circ}$ & $15.9^{b}$ & $201^{\mathrm{b}}$ & $5363^{\mathrm{c}}$ \\
\hline
\end{tabular}

$\dagger$ Values in the same column with different letters as superscript differ significantly $(\mathrm{P}<0.05)$

Table 3b. Mean neutral detergent fibre $(\mathrm{NDF}=$ cellulose + hemicellulose + lignin $)$ yield $\left(\mathrm{kg} \mathrm{ha}^{-1}\right)$ of silage maize at various growth stages $($ Cellulose $=\mathrm{CEL}$, Hemicellulose $=$ HEM and lignin $=$ LIG)

\begin{tabular}{|c|c|c|c|c|c|c|c|c|c|c|c|c|c|c|c|c|c|c|}
\hline \multirow{2}{*}{$\begin{array}{l}\text { Growth } \\
\text { stages }\end{array}$} & \multicolumn{3}{|c|}{ Zero } & \multicolumn{3}{|c|}{ Fresh } & \multicolumn{3}{|c|}{ Roofed } & \multicolumn{3}{|c|}{ Stockpiled } & \multicolumn{3}{|c|}{ Composted } & \multicolumn{3}{|c|}{ Covered } \\
\hline & CEL & HEM & LIG & CEL & HEM & LIG & CEL & HEM & LIG & CEL & HEM & LIG & CEL & HEM & LIG & CEL & HEM & LIG \\
\hline $\begin{array}{l}\text { End of } \\
\text { juvenile }\end{array}$ & $563^{\mathrm{a} \dagger}$ & $605^{\mathrm{a}}$ & $99^{\mathrm{a}}$ & $783^{a}$ & $912^{\mathrm{a}}$ & $119^{\mathrm{a}}$ & $819^{\mathrm{a}}$ & $883^{\mathrm{a}}$ & $151^{\mathrm{a}}$ & $832^{\mathrm{a}}$ & $912^{\mathrm{a}}$ & $125^{\mathrm{a}}$ & $833^{\mathrm{a}}$ & $864^{a}$ & $123^{\mathrm{a}}$ & $861^{\mathrm{a}}$ & $984^{\mathrm{a}}$ & $146^{\mathrm{a}}$ \\
\hline $\begin{array}{l}\text { Start of grain } \\
\text { filling }\end{array}$ & $2712^{\mathrm{b}}$ & $2738^{b}$ & $340^{\mathrm{b}}$ & $3510^{c}$ & $3563^{c}$ & $442^{c}$ & $3507^{c}$ & $3865^{c}$ & $334^{b}$ & $3537^{\mathrm{c}}$ & $4080^{c}$ & $324^{\mathrm{b}}$ & $3262^{\circ}$ & $3389^{\circ}$ & $308^{b}$ & $3871^{\mathrm{c}}$ & $4089^{c}$ & $404^{\mathrm{b}}$ \\
\hline $\begin{array}{l}\text { Physiological } \\
\text { maturity }\end{array}$ & $2713^{b}$ & $2948^{c}$ & $349^{b}$ & $2954^{b}$ & $2962^{b}$ & $333^{b}$ & $2765^{b}$ & $2931^{b}$ & $313^{b}$ & $2994^{\mathrm{b}}$ & $3328^{b}$ & $320^{\mathrm{b}}$ & $2888^{\mathrm{b}}$ & $3047^{b}$ & $329^{\mathrm{c}}$ & $2935^{\mathrm{b}}$ & $3043^{b}$ & $389^{b}$ \\
\hline
\end{tabular}



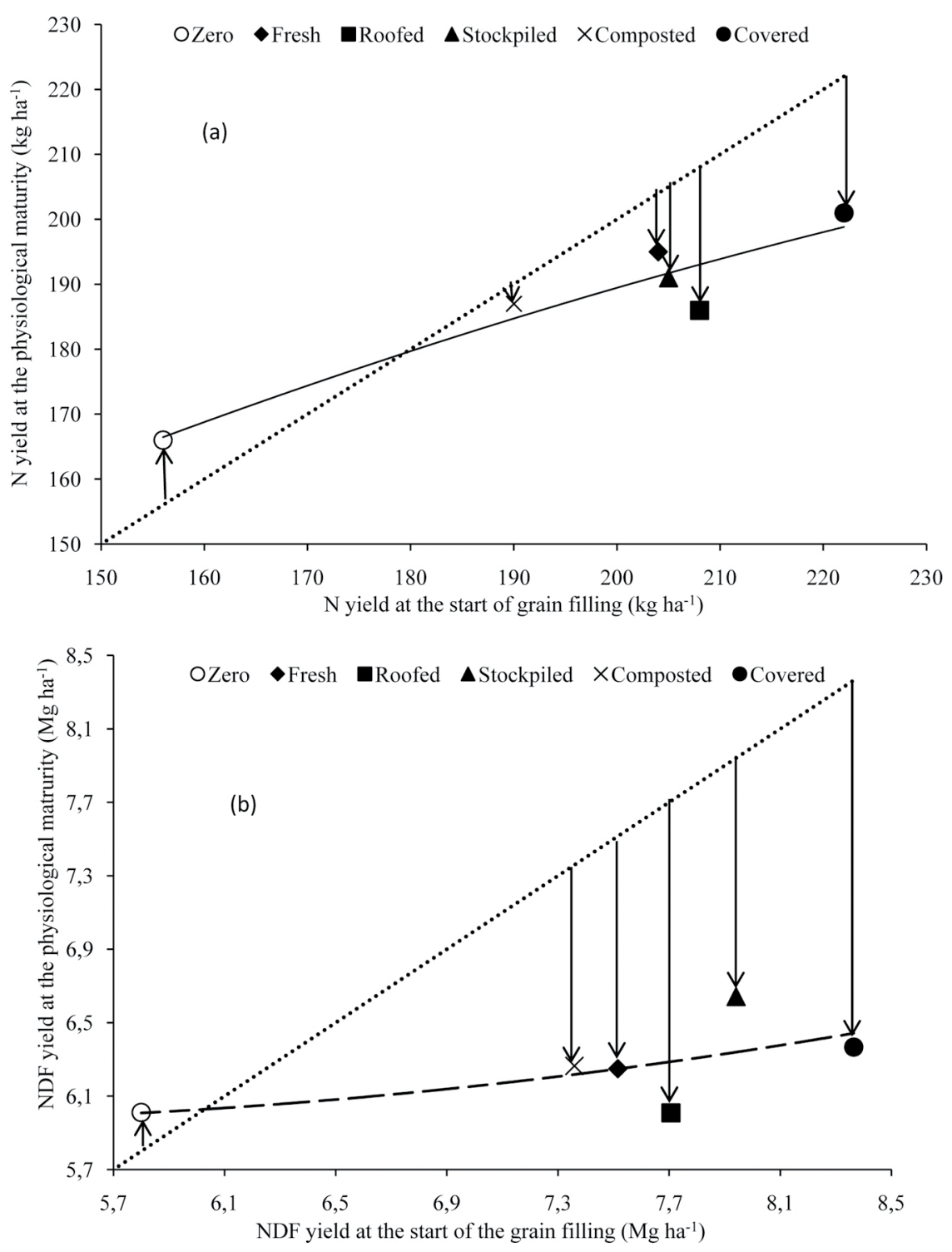

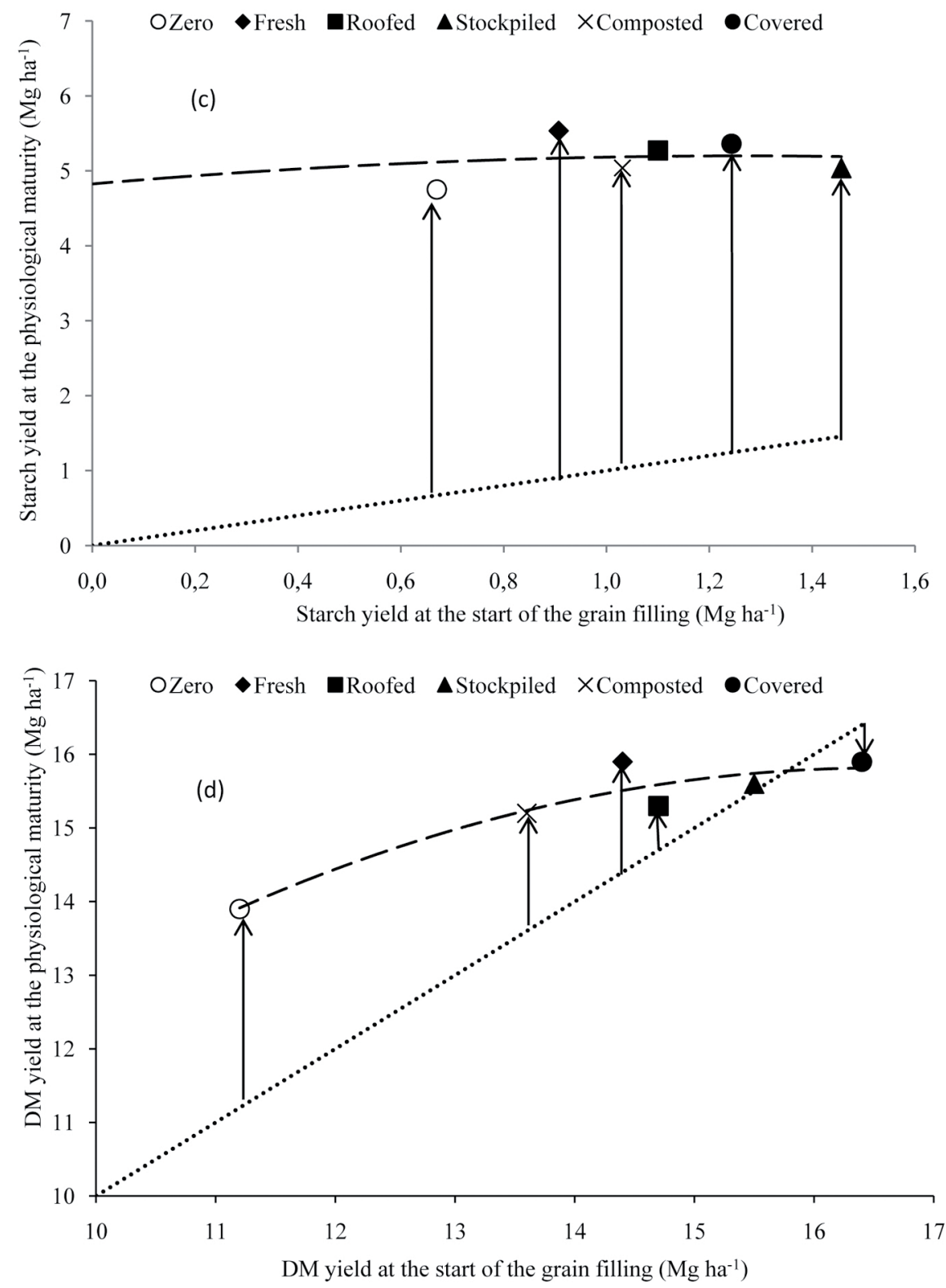

Figure 2a.b.c.d. Change in maize (a) nitrogen (N), (b) neutral detergent fibre (NDF), (c) starch and (d) dry matter (DM) yields between start of grain filling and physiological maturity growth stages of maize. The dotted and dashed lines represent 1:1 relationship and trend, respectively. Downward arrows indicate a decrease and upward arrow indicates an increase. 


\section{Conclusions}

This study revealed that total $\mathrm{N}$ losses during storage of SCM can be reduced greatly by covering the heaps with an impermeable sheet. After field application, covered manure substantially increased maize crop $\mathrm{N}$ recovery and DM yield, especially with regard to composted manure. This all, resulted in relatively higher apparent recovery of the manure $\mathrm{N}$ taken from the barn, over one maize growing season. Calculated maize ANR decreased between the start of grain filling stage and physiological maturity due to increase in $\mathrm{N}$ losses through leaf death (senescence). This warrants keeping in mind the crop developmental stage when carrying out fertilisation experiments with maize. All these findings lead us to conclude that covered storage is a promising means for helping to retain as much of the animal excreted $\mathrm{N}$ as possible for plants uptake (if managed properly).

\section{Acknowledgments}

This work was financed by the Higher Education Commission of Pakistan. We are equally indebted to Wageningen University for providing technical assistance for this project. We thank Ghulam Abbas gull, Nicolas Pugeaux, Muhammad Imtiaz Rashid and Pierre Crouigneau for their help in the field work and Hennie Halm for providing assistance in the laboratory work. Special thanks are due to Dr. Johannes Scholberg for critically reading the manuscript and Dr. Evert-Jan Bakker for his help in statistical analysis.

\section{References}

Amon, B., Amon, T.T., Boxberger, J., Alt, C. 2001. Emissions of $\mathrm{NH}_{3}, \mathrm{~N}_{2} \mathrm{O}$ and $\mathrm{CH}_{4}$ from dairy cows housed in a farmyard manure tying stall (housing, manure storage, manure spreading). Nutr. Cyc. Agroecosyst. 60, 103-113.
Anonymous. 1998. Manure and derivatives: Determination of the contents of dry matter and organic matter (in Dutch). Gravimetric method. Dutch Standardization Institute (NNI), Delft, the Netherlands.

Chadwick, D.R. 2005. Emissions of ammonia, nitrous oxide and methane from cattle manure heaps: Effect of compaction and covering. Atmos. Environ. 39, 787-799.

Dence, C.W. 1992. The determination of lignin. In: Lin, S.Y., Dence, C.W. (ed) Methods in lignin chemistry, Springer, Berlin. pp 33-61.

De Vries, J.W., Groenestein, C.M., Schröder, J.J., Hoogmoed, W.B., Sukkel, W., Groot Koerkamp, P.W.G., De Boer, I.J.M. 2015. Integrated manure management to reduce environmental impact: II. Environmental impact assessment of strategies. Agri. Syst. 38, 88-99.

Hansen, M.N, Henriksen. K., Sommer, S.G. 2006. Observations of production and emission of greenhouse gases and ammonia during storage of solids separated from pig slurry: Effects of covering. Atmos. Environ. 40, 4172-4181.

Hassouna, M., Espagnol, S., Robin, P., Paillat, J.M., Levasseur, P., Y. Li. 2008. Monitoring $\mathrm{NH}_{3}, \mathrm{~N}_{2} \mathrm{O}$, $\mathrm{CO}_{2}$ and $\mathrm{CH}_{4}$ emissions during pig solid manure storage and effect of turning. Compost Sci. Util. 16, 267-274.

Gungula, D.T., Kling, J.G., Togun, A.O. 2003. CERES-Maize predictions of maize phenology under nitrogen-stressed conditions in Nigeria. Agron. J. 95, 892-899.

Houba, V.J.G., Van Der Lee, J. J., Novozamsky, I., Walinga, I. 1989. Soil and plant analysis, a series of syllabi, Part 5. Wageningen University, the Netherlands.

Kirchmann, H. 1985. Losses, plant uptake and utilization of manure nitrogen during a production cycle. Acta Agri. Scand. Suppl. 24. 1-77. 
MAFF. 1986. The analysis of agricultural materials. MAFF/ADAS Reference Book 427. HMSO, London, United Kingdom.

Mosquera, J., Hol, J.M.G., Monteny, G.J. 2006. Gaseous emissions from a deep litter farming system for dairy cattle. In: Soliva, C. R., Takahashi, J., Kreuzer, M. (Eds.) Int Congr Ser, pp 291-294.

Ndegwa, P.M., Hristov, A.N., Arogo, J., Sheffield, R.E. 2008. A review of ammonia emission mitigation techniques for concentrated animal feeding operations. Biosyst. Eng. 100, 453-469.

Pardo, G., Moral, R., Aguilera, E., A.D. Prado. 2015. Gaseous emissions from management of solid waste: a systematic review. Glob. Change Biol. 21, 1313-1327.

Parkinson, R., Gibbs, P., Burchett, S., Misselbrook, T. 2004. Effect of turning regime and seasonal weather conditions on nitrogen and phosphorus losses during aerobic composting of cattle manure. Bioresour. Technol. 91, 171-178.

Pettygrove, G.S., Heinrich, A.L., Eagle, A.J. 2009. Dairy manure nutrient content and forms. Manure technical bulletin series. University of California Cooperative Extension.

Prioul, J.L., Schwebel-Dugué, N. 1992. Source-Sink Manipulations and Carbohydrate Metabolism in Maize. Crop Sci. 32, 751-756.

Rashid, M.I., de Goede, R.G.M., Brussaard, L., E.A. Lantinga., E.A. 2013. Home field advantage of cattle manure decomposition affects the apparent nitrogen recovery in production grassland. Soil Biol. Biochem. 57, 320-326.

Sagoo, E., Williams, J.R., Chambers, B.J., Boyles, L.O., Matthews, R., . Chadwick, D.R 2007. Integrated management practices to minimise losses and maximise the crop nitrogen value of broiler litter. Biosyst. Eng. 97, 512-519.
Scotti1, R., Bonanomi, G., Scelza, R., Zoina, A., Rao, M.A. 2015. Organic amendments as sustainable tool to recovery fertility in intensive agricultural systems. J. Soil Sci. Plant Nutr. 15, 333-352.

Schröder, J.J. 2005. Manure as a suitable component of precise nitrogen nutrition. In: Proceedings No. 574, International Fertiliser Society, York, UK, pp $1-30$.

Shah, G.A., Groot, J.C.J., Lantinga, E.A. 2013. Simulation of long-term carbon and nitrogen dynamics in grassland-based dairy farming systems to evaluate mitigation strategies for nutrient losses. PLoS One. 8, 672-679.

Shah, G.M., Groot, J.C.J., Oenema, O., Lantinga, E.A. 2012b Covered storage reduce losses and improve crop utilisation of nitrogen from solid cattle manure. Nutr. Cycl. Agroecosyst. 94, 299312.

Shah, G.A., Rashid, M.I., Shah, G.A., Groot, J.C.J., Lantinga, E.A. 2012a. Mineralization and herbage recovery of animal manure nitrogen after application to various soil types. Nutr. Cycl. Agroecosyst. 365, 69-79.

Shah, G.M., Shah, G.A., Groot, J.C.J., Oenema, O., Lantinga, E.A. 2012c. Irrigation and lava meal use reduce ammonia emission and improve $\mathrm{N}$ utilization when solid cattle manure is applied to grassland. Agric EcosystEnviron. 160, 59-65.

Shah G.M., Shah G.A., Groot J.C.J., Oenema O. Raza A.S. E.A. Lantinga . 2016. Effect of storage conditions on losses and crop utilisation of nitrogen from solid cattle manure J. Agric. Sci. Camb. 154, 58-71.

Takahashi, S., Uenosono, S., M. Nagatomo, M. 2004. Rice Uptake of Nitrogen from Aerobically and Anaerobically Composted Poultry Manure. J. Plant Nutr. 27, 731-741. 
Thomsen, I.K., Olesen, J.E. 2000. C and N mineralization of composted and anaerobically stored ruminant manure in differently textured soils. J. Agric. Sci. 135, 151-159.

Webb, J., Sommer, S.G., Kupper, T., Groenestein, K., Hutchings, N.J., Eurich-Menden, B., Rodhe, L., Misselbrook, T.H., Amon, B. 2012. Emissions of ammonia, nitrous oxide and methane during the management of solid manures. Sustain. Agri. Rev. 8, 67-107.
Yamulki, S. 2006. Effect of straw addition on nitrous oxide and methane emissions from stored farmyard manures. Agri. Ecosyst. Environ. 112, 140-145. 